\title{
Hubungan Pengetahuan dan Sikap Dengan Perilaku Pencegahan Demam Tifoid Pada Penjamah Makanan
}

\author{
Tyagita Widya Sari*1, Sri Wahyuni ${ }^{2}$ \\ 1,2Program Studi Pendidikan Dokter, Fakultas Kedokteran, Universitas Abdurrab, Indonesia \\ *Correspondence Email : tyagita.ws@univrab.ac.id
}

\begin{abstract}
Typhoid fever is a disease that attacks the digestive tract, caused by the bacteria Salmonella typhi. This disease can occur due to low personal hygiene, slum environmental sanitation, and habit of snacking carelessly. Typhoid fever prevention behavior in food handlers is needed to reduce the incidence of typhoid fever, where this behavior is influenced by the knowledge and attitudes of the food handlers about the prevention of typhoid fever.-The purpose of this research was to determine the correlation between knowledge and attitudes about typhoid fever prevention with typhoid fever prevention behavior in food handlers in Air Hitam Sub District Payung Sekaki District Pekanbaru City. The research method used an analytic survey with a cross sectional approach. The sampling technique used accidental sampling with a sample size of 30 respondents. The data analysis used the Spearman correlation test, because the data were not normally distributed. There was a relationship between knowledge about typhoid fever prevention and typhoid fever prevention behaviors among food handlers with moderate correlation strength and positive correlation direction ( $p$-value $=0.000$; $r=0.555)$. There was also a relationship between attitudes about typhoid fever prevention and typhoid fever prevention behaviors among food handlers with strong correlation strength and positive correlation direction ( $p$-value $=0.000 ; r=0.674)$. The conclusion of this research was knowledge and attitude about typhoid fever prevention correlate with typhoid fever prevention behaviors among food handlers in Air Hitam Sub District Payung Sekaki District Pekanbaru City.
\end{abstract}

Key words: Attitude, Food Handlers, Knowledge, Preventive Behavior, Typhoid Fever

\begin{abstract}
Abstrak
Demam tifoid adalah penyakit yang menyerang saluran pencernaan, yang disebabkan oleh bakteri Salmonella typhi. Penyakit ini dapat terjadi akibat personal hygiene yang rendah, sanitasi lingkungan yang kumuh, dan kebiasaan jajan sembarangan. Perilaku pencegahan demam tifoid pada penjamah makanan diperlukan dalam menurunkan angka kejadian demam tifoid, di mana perilaku ini dipengaruhi oleh pengetahuan dan sikap penjamah makanan tersebut tentang pencegahan demam tifoid. Tujuan penelitian ini adalah mngetahui hubungan pengetahuan dan sikap tentang pencegahan demam tifoid dengan perilaku pencegahan demam tifoid pada penjamah makanan di Kelurahan Air Hitam Kecamatan Payung Sekaki Kota Pekanbaru. Metode penelitian menggunakan survei analitik dengan pendekatan cross sectional. Teknik pengambilan sampel menggunakan accidental sampling dengan jumlah sampel 40 responden. Analisis data menggunakan uji korelasi Spearman, karena data tidak terdistribusi normal Hasil penelitian diperoleh ada hubungan antara pengetahuan tentang pencegahan demam tifoid dengan perilaku pencegahan demam tifoid pada penjamah makanan dengan kekuatan korelasi sedang dan arah korelasi positif ( $p$-value $=0,000 ; r=$ 0,555). Selain itu, diperoleh juga hubungan antara sikap tentang pencegahan demam tifoid dengan perilaku pencegahan demam tifoid pada penjamah makanan dengan kekuatan korelasi kuat dan arah korelasi positif ( $p$-value $=0,000 ; r=0,674)$. Kesimpulan penelitian ini yaitu pengetahuan dan sikap tentang pencegahan demam tifoid berhubungan dengan perilaku pencegahan demam tifoid pada penjamah makanan di Kelurahan Air Hitam Kecamatan Payung Sekaki Kota Pekanbaru.
\end{abstract}

Kata kunci : Demam Tifoid, Pengetahuan, Penjamah Makanan, Perilaku Pencegahan, Penjamah Makanan

Received: November 2021, Accepted : November 2021 - Jurnal Photon Vol.12 No.1

DOI : https://doi.org/10.37859/jp.v12i1.3166

PHOTON is licensed under a Creative Commons Attribution-ShareAlike 4.0 International License 


\section{Introduction}

Demam tifoid adalah penyakit menular yang disebabkan oleh bakteri Salmonella typhi. Infeksi Salmonella typhi ditularkan apabila mengkonsumsi makanan dan air yang terkontaminasi oleh feses dan urin pasien yang mengalami demam tifoid. Penyakit ini sangat mudah menular dan dapat menyerang banyak orang sehingga dapat menimbulkan suatu wabah (Nyamusore et al., 2018). Demam tifoid merupakan penyakit infeksi akut pada usus halus dengan gejala demam kurang lebih satu minggu yang disertai dengan gangguan pada saluran pencernaan. Demam tifoid ini sangat berbahaya jika tidak ditangani dengan baik yang dapat menyebabkan kematian (Setiati \& Alwi, 2017).

Menurut World Health Organization (WHO) 2016 secara global kejadian demam tifoid diperkirakan setiap tahunnya terjadi sekitar 21 juta kasus dan 222.000 diantaranya menyebabkan kematian. Prevalensi kejadian demam tifoid di negara maju mencapai 5.700 kasus setiap tahun. Prevalensi kejadian demam tifoid pada negara berkembang mencapai sekitar 21,5 juta setiap tahun (Ulfa \& Handayani, 2018). Pada tahun 2010 Departemen Kesehatan RI menyampaikan bahwa angka kejadian demam tifoid menempati urutan ke-3 dari beberapa penyakit pada pasien rawat inap di rumah sakit yang ada di Indonesia (Setiati \& Alwi, 2017).

Di Indonesia penyakit demam tifoid bersifat endemik, yaitu sebuah penyakit pada suatu wilayah tertentu yang menetap dalam waktu lama, di mana menurut WHO angka kejadian demam tifoid di Indonesia mencapai $81 \%$ per 100.000 penduduk. Sampai saat ini demam tifoid masih termasuk masalah kesehatan di negara-negara yang beriklim tropis salah satunya Indonesia dengan angka kejadian demam tifoid 760810 kasus per tahun dan angka kematian mencapai sekitar 3,1-10,4\%. Kasus demam tifoid di Indonesia tersebar rata di seluruh provinsi dengan insidensi di daerah perkotaan sekitar 358/100.000 penduduk/tahun dan di daerah pedesaan sekitar 760/100.000 penduduk/tahun (Ramaningrum, Anggraheny, \& Puteri, 2016). Berdasarkan data yang didapatkan dari Dinas Kesehatan Provinsi Riau jumlah kasus demam tifoid di Kota Pekanbaru pada tahun 2018 yaitu sebanyak 122 kasus, dan pada tahun 2019 meningkat sebanyak 150 kasus (Dinas Kesehatan Kota Pekanbaru, 2019).

Terjadinya peningkatan kasus demam tifoid disebabkan karena demam tifoid merupakan penyakit multifaktorial yaitu penyakit yang dapat dipicu oleh banyak faktor, antara lain umur, jenis kelamin, pendidikan, pekerjaan, sanitasi lingkungan, kebersihan diri (personal hygiene), dan tempat tinggal. Perilaku pencegahan demam tifoid diperlukan dalam menurunkan angka kejadian tifoid, di mana perilaku ini dipengaruhi oleh pengetahuan dan sikap tentang pencegahan demam tifoid. Perilaku pencegahan demam tifoid antara lain kebersihan diri (personal hygiene) meliputi kebiasaan cuci tangan, kebiasaan makan dan minum, pola makan, dan sanitasi lingkungan (Ulfa \& Handayani, 2018).

Received: November 2021, Accepted : November 2021 - Jurnal Photon Vol.12 No.1

DOI : https://doi.org/10.37859/jp.v12i1.3166

PHOTON is licensed under a Creative Commons Attribution-ShareAlike 4.0 International License 
Indonesia merupakan salah satu negara di Asia Tenggara yang mempunyai kualitas pangan yang rendah, karena erat kaitannya dengan penerapan hygiene dan sanitasi dalam proses pengelolaan makanan oleh penjamah makanan. Penjamah makanan harus menerapkan hygiene dan sanitasi lingkungan kerja yang baik di mana sangat bermanfaat untuk penjamah makanan tersebut, yaitu dapat terhindar dari makanan yang terkontaminasi, dan kualitas makanan akan terjamin (Pasanda, 2016).

Penerapan hygiene dan sanitasi dalam proses pengelolaan pangan dikenal sebagai Good Manufacturing Practices (GMP) sudah diterapkan. Akan tetapi, di negara-negara berkembang metode yang digunakan dikenal dengan Cara Pengolahan Pangan yang Baik (CPPB) belum diterapkan, baik di industri yang bergerak di bidang pangan dalam skala industri besar maupun industri kecil. Oleh karena itu, hal ini sangat berisiko dapat menyebabkan gangguan kesehatan mulai dari diare, kecacingan, demam tifoid, atau pun terjadinya keracunan makanan. Adapun perilaku yang tidak baik oleh penjamah makanan dalam menyajikan atau mengelola makanan sangat beragam mulai dari menggaruk anggota badan, tidak mencuci tangan dengan air mengalir dan sabun, mencuci makanan tidak dengan air mengalir, memiliki kuku yang panjang, tidak menutup makanan yang sudah disajikan sehingga menyebabkan kontaminasi pada makanan. Perilaku penjamah makanan yang kurang baik ini sangat berhubungan erat dengan pengetahuan dan sikap penjamah makanan dalam pentingnya menjaga hygiene yang baik dalam mengelola makanan. Pada saat sini begitu banyak pedagang makanan tidak menerapkan hygiene yang baik dalam mengelola makanan/pangan, sehingga perilaku penjamah makanan yang kurang baik dapat meningkatkan risiko besar pada masalah kesehatan masyarakat yaitu timbulnya penyakit, salah satunya kejadian demam tifoid (Pasanda, 2016).

Pedagang makanan banyak menjual dagangan terutama di pinggir jalan dan di keramaian. Salah satu pedagang makanan pinggiran banyak ditemukan di sekolah dan di institusi pendidikan lainnya antara lain pedagang makanan yang ada di sekitar kampus Universitas Abdurrab, yang berlokasi di Kelurahan Air Hitam, Kecamatan Payung Sekaki, Kota Pekanbaru. Berdasarkan survei pendahuluan yang dilakukan di mana banyak pedagang makanan pinggiran berjualan mulai dari gorengan, pentol, siomay, batagor, lontong, dan makanan serta minuman lainnya yang belum terjamin kebersihannya. Banyak mahasiswa yang membeli makanan dan minuman tersebut, karena mahasiswa jarang memasak makanan sendiri akibat kesibukan di perkuliahan dan keterbatasan waktu, sehingga mereka lebih cenderung memilih membeli makanan siap saji di luar.

Berdasarkan penelitian yang dilakukan sebelumnya (Miranti \& Adi, 2016) di mana hasil penelitian menunjukkan bahwa sebagian besar pengetahuan responden (55,0\%) dan sikap responden temasuk dalam kategori baik, sedangkan sebagian besar hygiene perorangan termasuk dalam kategori sedang $(85,0 \%)$. Hasil uji hubungan menunjukkan bahwa tidak ada hubungan antara pengetahuan dengan sikap penjamah makanan ( $p$-value $>0,10)$, namun terdapat hubungan antara pengetahuan dengan hygiene perorangan

Received: November 2021, Accepted : November 2021 - Jurnal Photon Vol.12 No.1

DOI : https://doi.org/10.37859/jp.v12i1.3166

PHOTON is licensed under a Creative Commons Attribution-ShareAlike 4.0 International License 
penjamah makanan ( $p$-value $<0,10)$. Kesimpulan penelitian ini adalah pengetahuan bukan merupakan satu-satunya faktor yang dapat mempengaruhi sikap, namun pengetahuan adalah salah satu faktor yang dapat mempengaruhi hygiene penjamah makanan.

Berdasarkan latar belakang yang telah diuraikan, peneliti tertarik untuk meneliti hubungan pengetahuan dan sikap tentang pencegahan demam tifoid dengan perilaku pencegahan demam tifoid pada penjamah makanan dikarenakan banyak penjamah makanan yang memiliki hygiene yang kurang baik dan banyak masyarakat yang sangat berminat terhadap makanan siap saji termasuk mahasiswa.

\section{The Methods}

Penelitian ini bersifat kuantitatif analitik observasional menggunakan desain studi cross sectional. Variabel independen pada penelitian ini adalah pengetahuan dan sikap tentang pencegahan demam tifoid, sedangkan variabel dependen pada penelitian ini adalah perilaku pencegahan demam tifoid. Penelitian ini dilakukan oleh peneliti dengan dibantu oleh tiga asisten peneliti yang telah diberi briefing terkait penelitian terlebih dahulu.

Kuesioner pada penelitian ini dirumuskan sendiri oleh peneliti berdasarkan teori perilaku pencegahan demam tifoid (Kementerian Kesehatan RI, 2006). Kuesioner pengetahuan tentang pencegahan demam tifoid terdiri dari 10 item pertanyaan dengan pilihan jawaban tahu dan tidak tahu. Apabila responden menjawab tahu maka diberi skor 1 , sedangkan apabila responden menjawab tidak tahu maka diberi skor 0 . Kuesioner sikap tentang pencegahan demam tifoid terdiri dari 10 item pertanyaan dengan pilihan jawaban setuju dan tidak setuju. Apabila responden menjawab setuju maka akan diberi skor 1, sedangkan apabila responden menjawab tidak setuju maka akan diberi skor 0 . Kuesioner perilaku tentang pencegahan demam tifoid terdiri dari 10 item pertanyaan dengan pilihan jawaban ya dan tidak. Apabila responden menjawab ya maka akan diberi skor 1 , sedangkan apabila responden menjawab tidak maka akan diberi skor 0. Rentang skor minimal dan maksimal untuk masing-masing variabel pengetahuan tentang pencegahan demam tifoid, sikap tentang pencegahan demam tifoid, dan perilaku pencegahan demam tifoid adalah 0-10. Kuesioner ini telah dilakukan uji validitas dan reliabilitas terlebih dahulu. Hasil uji menyatakan bahwa kuesioner valid (nilai $r$ hitung setiap item pernyataan > $r$ tabel $(0,312)$ ) dan reliabel (nilai Cronbach's alpha seluruh variabel >0,60).

Sampel dalam penelitian ini adalah sebagian penjamah makanan yang berjualan di Kelurahan Air Hitam Kecamatan Payung Sekaki Kota Pekanbaru yang berjumlah 30 orang. Teknik pengambilan sampel pada penelitian ini adalah accidental sampling. Pengambilan sampel dilakukan selama 3 hari. Kriteria inklusi sampel pada penelitian ini adalah responden yang berjualan di di Kelurahan Air Hitam Kecamatan Payung Sekaki yang bersedia menjadi responden dengan menandatangani informed consent penelitian. Analisis data yang digunakan adalah analisis bivariat menggunakan uji korelasi Spearman Rank karena data tidak terdistribusi normal.

Received: November 2021, Accepted : November 2021 - Jurnal Photon Vol.12 No.1

DOI : https://doi.org/10.37859/jp.v12i1.3166

PHOTON is licensed under a Creative Commons Attribution-ShareAlike 4.0 International License 


\section{Result and Discussion}

\section{a. Result}

Tabel 1. Distribusi Frekuensi Responden Penjamah Makanan di Kelurahan Air Hitam Kecamatan Payung Sekaki Kota Pekanbaru

\begin{tabular}{|c|c|c|c|}
\hline \multirow[t]{2}{*}{ No } & \multirow[t]{2}{*}{ Variabel } & \multicolumn{2}{|c|}{ Proporsi } \\
\hline & & $\mathrm{n}$ & $\%$ \\
\hline \multirow[t]{3}{*}{1.} & Umur & & \\
\hline & a. $<45$ tahun & 30 & 75 \\
\hline & b. $>45$ tahun & 10 & 25 \\
\hline \multirow[t]{3}{*}{2.} & Jenis Kelamin & & \\
\hline & a. Laki-laki & 19 & 47,5 \\
\hline & b. Perempuan & 21 & 52,5 \\
\hline \multirow[t]{3}{*}{3.} & Lama Bekerja & & \\
\hline & a. $>3$ tahun & 27 & 67,5 \\
\hline & b. $<3$ tahun & 13 & 32,5 \\
\hline \multirow[t]{4}{*}{4.} & Tingkat Pendidikan & & \\
\hline & a. SD & 20 & 50 \\
\hline & b. SMP & 8 & 20 \\
\hline & c. SMA & 12 & 30 \\
\hline \multirow[t]{4}{*}{5.} & Tingkat Pengetahuan & & \\
\hline & a. Baik & 25 & 62,5 \\
\hline & b. Cukup & 9 & 22,5 \\
\hline & c. Kurang & 6 & 15 \\
\hline \multirow[t]{4}{*}{6.} & Tingkat Sikap & & \\
\hline & a. Baik & 22 & 55 \\
\hline & b. Cukup & 12 & 30 \\
\hline & c. Kurang & 6 & 15 \\
\hline \multirow[t]{4}{*}{7.} & Tingkat Perilaku & & \\
\hline & a. Baik & 27 & 67,5 \\
\hline & b. Cukup & 8 & 20 \\
\hline & c. Kurang & 45 & 12,5 \\
\hline
\end{tabular}

Berdasarkan Tabel 1 dapat diketahui bahwa sebagian besar responden memiliki kategori umur kurang dari 45 tahun yaitu sebanyak 30 orang (75,0\%), sebagian besar responden memiliki jenis kelamin perempuan yaitu sebanyak 21 orang (52,5\%), sebagian besar responden memiliki kategori lama bekerja di atas 3 tahun yaitu sebanyak 27 orang $(67,5 \%)$, dan responden paling banyak termasuk kategori tingkat pendidikan SD yaitu sebanyak 20 orang (50,0\%). Selain itu, dapat diketahui pula bahwa sebagian besar responden memiliki tingkat pengetahuan tentang pencegahan demam tifoid baik yaitu sebanyak 25 orang $(62,5 \%)$, sebagian besar responden memiliki sikap tentang pencegahan demam tifoid baik yaitu sebanyak 22 orang $(55,0 \%)$, dan sebagian besar responden memiliki perilaku pencegahan demam tifoid baik yaitu sebanyak 27 orang $(67,5 \%)$.

Received: November 2021, Accepted : November 2021 - Jurnal Photon Vol.12 No.1

DOI : https://doi.org/10.37859/jp.v12i1.3166

PHOTON is licensed under a Creative Commons Attribution-ShareAlike 4.0 International License 
Tabel 2. Hasil Uji Normalitas Data

\begin{tabular}{lcl}
\hline \multicolumn{1}{c}{ Variabel } & $\begin{array}{c}\text { Uji Shapiro Wilk } \\
(\boldsymbol{p} \text {-value })\end{array}$ & \multicolumn{1}{c}{ Kesimpulan } \\
\hline $\begin{array}{l}\text { Pengetahuan tentang } \\
\text { pencegahan demam tifoid }\end{array}$ & 0,001 & $\begin{array}{l}\text { Data tidak terdistribusi } \\
\text { normal }(p \text {-value }<0,05)\end{array}$ \\
\hline $\begin{array}{l}\text { Sikap tentang pencegahan } \\
\text { demam tifoid }\end{array}$ & 0,048 & $\begin{array}{l}\text { Data tidak terdistribusi } \\
\text { normal }(p \text {-value }<0,05)\end{array}$ \\
\hline $\begin{array}{l}\text { Perilaku pencegahan demam } \\
\text { tifoid }\end{array}$ & 0,002 & $\begin{array}{l}\text { Data tidak terdistribusi } \\
\text { normal }(p \text {-value }<0,05)\end{array}$ \\
\hline
\end{tabular}

Berdasarkan Tabel 2, dapat disimpulkan bahwa seluruh variabel penelitian memiliki data yang tidak terdistribusi normal ( $p$-value $<0,05)$, maka pengujian hipotesis menggunakan uji korelasi Spearman Rank.

Tabel 3. Hubungan Pengetahuan Dengan Perilaku Pencegahan Demam Tifoid Pada Penjamah Makanan di Kelurahan Air Hitam Kecamatan Payung Sekaki Kota Pekanbaru

\begin{tabular}{lllcc}
\hline & & \multicolumn{2}{c}{$\begin{array}{c}\text { Pengetahuan } \\
\text { tentang } \\
\text { pencegahan } \\
\text { demam tifoid }\end{array}$} & $\begin{array}{c}\text { Perilaku } \\
\text { pencegahan } \\
\text { demam tifoid }\end{array}$ \\
\hline $\begin{array}{l}\text { Spearman's } \\
\text { rho }\end{array}$ & $\begin{array}{l}\text { Pengetahuan } \\
\text { tentang } \\
\text { pencegahan } \\
\text { demam tifoid }\end{array}$ & $\mathrm{r}$ & 1,000 & 0,555 \\
\cline { 2 - 5 } & $\begin{array}{l}\text { Perilaku } \\
\text { pencegahan } \\
\text { demam tifoid }\end{array}$ & $\mathrm{N}$ & 40 & 0,000 \\
\cline { 2 - 5 } & $\mathrm{N}$ & 0,550 & 40 \\
\hline \hline
\end{tabular}

Berdasarkan Tabel 3 diperoleh nilai p-value sebesar 0,000 dan nilai koefisien korelasi (r) sebesar 0,555. Jadi, dapat disimpulkan bahwa terdapat hubungan yang signifikan antara pengetahuan dengan perilaku pencegahan demam tifoid, dengan arah hubungan positif dan kekuatan hubungan sedang.

Tabel 4. Hubungan Sikap Dengan Perilaku Pencegahan Demam Tifoid Pada Penjamah Makanan di Kelurahan Air Hitam Kecamatan Payung Sekaki

Kota Pekanbaru

\begin{tabular}{|c|c|c|c|c|}
\hline & & & $\begin{array}{l}\text { Sikap tentang } \\
\text { pencegahan } \\
\text { demam tifoid } \\
\end{array}$ & $\begin{array}{c}\text { Perilaku } \\
\text { pencegahan } \\
\text { demam tifoid } \\
\end{array}$ \\
\hline \multirow[t]{6}{*}{ Spearman's rho } & \multirow{3}{*}{$\begin{array}{l}\text { Sikap tentang } \\
\text { pencegahan } \\
\text { demam tifoid }\end{array}$} & $\mathrm{r}$ & 1,000 & 0,674 \\
\hline & & $p$-value & . & 0,000 \\
\hline & & $\mathrm{N}$ & 40 & 40 \\
\hline & \multirow{3}{*}{$\begin{array}{l}\text { Perilaku } \\
\text { pencegahan } \\
\text { demam tifoid }\end{array}$} & $\mathrm{r}$ & 0,674 & 1,000 \\
\hline & & p-value & 0,000 & . \\
\hline & & $\mathrm{N}$ & 40 & 40 \\
\hline
\end{tabular}

Received: November 2021, Accepted : November 2021 - Jurnal Photon Vol.12 No.1

DOI : https://doi.org/10.37859/jp.v12i1.3166

PHOTON is licensed under a Creative Commons Attribution-ShareAlike 4.0 International License 
Berdasarkan Tabel 4 diperoleh nilai p-value sebesar 0,000 dan nilai koefisien korelasi (r) sebesar 0,674. Jadi, dapat disimpulkan bahwa terdapat hubungan yang signifikan antara sikap dengan perilaku pencegahan demam tifoid dengan arah hubungan positif dan kekuatan hubungan kuat.

\section{b. Discussion}

\section{Hubungan Pengetahuan Dengan Perilaku Pencegahan Demam Tifoid Pada Penjamah Makanan} di Kelurahan Air Hitam Kecamatan Payung Sekaki Kota Pekanbaru

Berdasarkan analisis statistik yang dilakukan dengan menggunakan uji korelasi Spearman Rank mengenai hubungan pengetahuan dengan perilaku pencegahan demam tifoid pada penjamah makanan di Kecamatan Payung Sekaki Kota Pekanbaru, didapatkan hasil p-value 0,000 dengan nilai koefisien korelasi (r) yaitu sebesar 0,555. Jadi, dapat disimpulkan bahwa terdapat hubungan antara pengetahuan dengan perilaku pencegahan demam tifoid pada penjamah makanan di Kecamatan Payung Sekaki Kota Pekanbaru, dengan kekuatan hubungan yang sedang dan arah korelasi positif. Jadi, semakin tinggi pengetahuan tentang pencegahan demam tifoid, maka perilaku pencegahan demam tifoid akan semakin baik, demikian pula sebaliknya.

Dari hasil penelitian ini diketahui bahwa dari 5 responden (12,5\%) dengan perilaku pencegahan demam tifoid kurang, sebanyak 4 responden (10\%) memiliki pengetahuan kurang tentang pencegahan demam tifoid dan 1 responden (2,5\%) memiliki pengetahuan cukup tentang pencegahan demam tifoid. Dari 8 responden $(20,0 \%)$ dengan perilaku pencegahan demam tifoid cukup, sebanyak 1 responden $(2,5 \%)$ memiliki pengetahuan kurang tentang pencegahan demam tifoid, 2 responden (5\%) memiliki pengetahuan cukup tentang pencegahan demam tifoid, dan 1 responden (2,5\%) memiliki pengetahuan baik tentang pencegahan demam tifoid. Dari 27 responden (67,5\%) dengan perilaku pencegahan demam tifoid baik, sebanyak 1 responden (2,5\%) memiliki pengetahuan kurang tentang pencegahan demam tifoid, 6 responden (15\%) memiliki pengetahuan cukup tentang pencegahan demam tifoid, dan 20 responden (50\%) memiliki pengetahuan baik tentang pencegahan demam tifoid.

Jadi, dapat diambil kesimpulan bahwa sebagian besar responden yang memiliki perilaku pencegahan demam tifoid kurang memiliki pengetahuan tentang pencegahan demam tifoid yang kurang pula yaitu 4 dari 5 responden (80\%). Sebaliknya, sebagian besar responden dengan perilaku pencegahan demam tifoid baik memiliki pengetahuan tentang pencegahan demam tifoid yang baik pula yaitu 20 dari 27 responden (74,07\%). Adapun sebagian besar responden yang memiliki perilaku pencegahan demam tifoid cukup memiliki pengetahuan tentang pencegahan demam tifoid yang baik yaitu 5 dari 8 responden (62,5\%).

Hasil penelitian ini sesuai dengan penelitian yang menyatakan bahwa ada hubungan yang bermakna antara pengetahuan dengan hygiene penjamah makanan. Hasil penelitian ini sejalan juga dengan penelitian bahwa orang yang memiliki pengetahuan tinggi tentang pencegahan demam tifoid dapat berpengaruh terhadap

Received: November 2021, Accepted : November 2021 - Jurnal Photon Vol.12 No.1

DOI : https://doi.org/10.37859/jp.v12i1.3166

PHOTON is licensed under a Creative Commons Attribution-ShareAlike 4.0 International License 
perilaku pencegahan demam tifoid yang baik. Menurut penelitian yang dilakukan oleh juga menyatakan bahwa ada hubungan antara pengetahuan dengan pencegahan kontaminasi makanan oleh penjamah makanan (Mardhatillah, 2019).

Menurut (Notoatmodjo, 2014), pengetahuan merupakan hasil dari tahu, dan ini terjadi setelah orang melakukan penginderaan terhadap suatu obyek tertentu. Penginderaan terjadi melalui panca indera manusia, yaitu penglihatan, pendengaran, penciuman, perasa dan peraba. Sebagian besar pengetahuan manusia diperoleh melalui mata dan telinga. Pengetahuan atau kognitif merupakan domain yang sangat penting untuk terbentuknya tindakan seseorang, sebab dari pengalaman dan hasil penelitian ternyata perilaku yang didasari oleh pengetahuan akan lebih baik daripada perilaku yang tidak didasari dengan pengetahuan.

Menurut (Mardhatillah, 2019), pengetahuan bagi penjamah makanan sangat penting untuk menghindari terjadinya penularan penyakit melalui makanan yang disebabkan oleh tenaga pengolahan makanan. Dengan meningkatnya pengetahuan masyarakat terhadap hygiene sanitasi penjamah makanan maka akan memberikan pengaruh terhadap masyarakat untuk mengolah makanan dengan baik dan sehat. Semakin tinggi pengetahuan seseorang tentang pengolahan makanan, maka semakin baik pula caranya mengolah makanan sehingga makanan tersebut tetap memiliki nilai gizi yang tinggi.

\section{Hubungan Sikap Dengan Perilaku Pencegahan Demam Tifoid Pada Penjamah Makanan di Kelurahan Air Hitam Kecamatan Payung Sekaki Kota Pekanbaru}

Berdasarkan analisis statistik yang dilakukan dengan menggunakan uji korelasi Spearman mengenai hubungan sikap dengan perilaku pencegahan demam tifoid pada penjamah makanan di Kecamatan Payung Sekaki Kota Pekanbaru, didapatkan hasil $p$-value sebesar 0,000 dengan nilai koefisien korelasi (r) sebesar 0,674 . Jadi, dapat disimpulkan bahwa terdapat hubungan antara sikap dengan perilaku pencegahan demam tifoid pada penjamah makanan di Kecamatan Payung Sekaki Kota Pekanbaru dengan kekuatan hubungan yang kuat dengan arah korelasi positif. Jadi, semakin baik sikap tentang pencegahan demam tifoid, maka perilaku pencegahan demam tifoid akan semakin baik, demikian pula sebaliknya.

Dari hasil penelitian yang telah dilakukan diketahui bahwa dari 5 responden $(12,5 \%)$ dengan perilaku pencegahan demam tifoid kurang, sebanyak 4 responden (10\%) memiliki sikap kurang tentang pencegahan demam tifoid dan sebanyak 1 responden $(2,5 \%)$ memiliki sikap baik tentang pencegahan demam tifoid. Dari 8 responden (20,0\%) dengan perilaku pencegahan demam tifoid cukup, sebanyak 1 responden $(2,5 \%)$ memiliki sikap kurang tentang pencegahan demam tifoid, 6 responden (15\%) memiliki sikap cukup tentang pencegahan demam tifoid, dan 5 responden (15\%) memiliki sikap baik tentang pencegahan demam tifoid. Dari 27 responden (67,5\%) dengan perilaku pencegahan demam tifoid baik, sebanyak 1 responden $(2,5 \%)$ memiliki sikap kurang tentang pencegahan demam tifoid, 6 responden

Received: November 2021, Accepted : November 2021 - Jurnal Photon Vol.12 No.1

DOI : https://doi.org/10.37859/jp.v12i1.3166

PHOTON is licensed under a Creative Commons Attribution-ShareAlike 4.0 International License 
(15\%) memiliki sikap cukup tentang pencegahan demam tifoid, dan 20 responden (50\%) memiliki sikap baik tentang pencegahan demam tifoid.

Jadi, dapat diambil kesimpulan bahwa sebagian besar responden perilaku pencegahan demam tifoid kurang memiliki sikap tentang pencegahan demam tifoid yang kurang pula yaitu 4 dari 6 responden (66,67\%). Sebaliknya, sebagian besar responden dengan perilaku pencegahan demam tifoid baik memiliki sikap tentang pencegahan demam tifoid baik pula yaitu 20 dari 27 responden. Adapun sebagian besar responden perilaku pencegahan demam tifoid cukup memiliki sikap tentang pencegahan demam tifoid yang cukup pula yaitu 6 dari 8 responden (75\%).

Hasil penelitian ini sesuai dengan penelitian (Amalia, Rohaeni, \& Muriawati, 2015), yang menyatakan bahwa ada hubungan antara sikap dengan perilaku pencegahan penyakit pada penjamah makanan. Hal ini dapat dilihat bahwa antara responden yang mempunyai sikap yang mendukung $(49,1 \%)$ dan sikap yang tidak mendukung $(50,9 \%)$ hampir seimbang. Praktik yang baik dipengaruhi oleh sikap yang baik pula, kemudian faktor pendorong yang paling berperan dalam praktek hygiene adalah pengawasan dalam penerapan prinsip-prinsip hygiene sanitasi makanan, baik dilakukan oleh pemilik tempat pengelolaan makanan maupun dari pihak lain misalnya dari petugas kesehatan lingkungan puskesmas.

Menurut (Maghafirah, Sukismanto, \& Rahmuniyati, 2018) sikap adalah tingkah laku yang tersembunyi yang terjadi secara disadari ataupun tidak disadari. Hal ini dapat disimpulkan bahwa responden hanya mengetahui tentang hygiene tanpa diterapkan melalui sikap atau kesadarannya, sehingga mempengaruhi dalam melakukan praktik hygiene pada saat pengolahan makanan. Menurut (Oktafiani \& Hendriyani, 2015), sikap merupakan kesiapan atau kesediaan untuk bertindak dan bukan merupakan pelaksanaan motif tertentu. Sikap belum merupakan tindakan atau aktivitas, akan tetapi merupakan predisposisi tindakan atau perilaku. Agar sikap dapat menjadi suatu perubahan nyata diperlukan adanya kondisi tertentu antara lain fasilitas dan dukungan. Sikap merupakan hal penting dalam kehidupan sehari-hari, karena kalau sikap sudah terbentuk dalam diri seseorang maka sikap tersebut dapat ikut dalam menentukan tingkah laku seseorang itu terhadap sesuatu. Menurut (Notoatmodjo, 2010) sikap merupakan proses berlangsung dalam diri seseorang yang di dalamnya dapat pengalaman individu yang akan mengarahkan dan menentukan respon terhadap berbagai objek dan situasi. Jadi, sikap merupakan reaksi atau respon yang masih tertutup dari seseorang terhadap suatu stimulus atau objek. Orang yang memiliki sikap yang baik terhadap sutau hal, ia akan memiliki perilaku atau tindakan yang baik pula.

Menurut (Miranti \& Adi, 2016) faktor yang memengaruhi sikap yaitu pengalaman pribadi, pengalaman orang lain yang dianggap penting, pengaruh kebudayaan, media massa, lembaga pendidikan, dan lembaga agama, serta faktor emosional. Selain itu, terdapat hubungan tentang sikap tehadap perilaku pencegahan penyakit pada penjamah makanan, dimana semakin baik sikap seseorang maka semakin baik pula perilaku personal hygiene seseorang tersebut. Penelitian yang dilakukan oleh (Mardhatillah, 2019) menyatakan

Received: November 2021, Accepted : November 2021 - Jurnal Photon Vol.12 No.1

DOI : https://doi.org/10.37859/jp.v12i1.3166

PHOTON is licensed under a Creative Commons Attribution-ShareAlike 4.0 International License 
bahwa seseorang dengan sikap yang positif maka akan memberikan pengarahan untuk penjamah makanan dalam melakukan pengolahan makanan yang baik dan benar-benar dalam menjaga kebersihan dan keamanan makanan bagi kesehatan agar tidak terkontaminasi. Selain itu, diupayakan pula proses pengolahan hingga penyajian makanan yang dilakukan sebaik mungkin sehingga menghasilkan makanan yang sehat.

\section{Conclusion}

Berdasarkan hasil dan pembahasan penelitian tentang hubungan pengetahuan dan sikap dengan perilaku pencegahan demam tifoid pada penjamah makanan di Payung Sekaki Kota Pekanbaru, dapat diambil kesimpulan sebagai berikut:

1. Ada hubungan pengetahuan dengan perilaku pencegahan demam tifoid pada penjamah makanan di Kelurahan Air Hitam Kecamatan Payung Sekaki Kota Pekanbaru, dengan kekuatan korelasi sedang dan arah korelasi positif ( $p$-value $=0,000 ; r=0,555$ ).

2. Ada hubungan sikap dengan perilaku pencegahan demam tifoid pada penjamah makan di Kelurahan Air Hitam Kecamatan Payung Sekaki Kota Pekanbaru, dengan kekuatan korelasi kuat dan arah korelasi positif ( $p$-value $=0,000 ; \mathrm{r}=0,674$ )

\section{Acknowledgement}

Terima kasih diucapkan kepada seluruh responden yang bersedia berpartisipasi dalam penelitian ini antara lain penjamah makanan di Kelurahan Air Hitam Kecamatan Payung Sekaki Kota Pekanbaru.

\section{References}

Amalia, I. S., Rohaeni, E., \& Muriawati, D. (2015). Hubungan Pengetahuan dan Sikap Dengan Praktik Hygiene Sanitasi Penjamah Makanan di Kecamatan Kadugede Kabupaten Kuningan Tahun 2013. Jurnal Ilmu-Ilmu Kesehatan Bhakti Husada Kuningan, 4(2), 52-57. Retrieved from https://ejournal.stikku.ac.id/index.php/stikku/article/view/42/29

Dinas Kesehatan Kota Pekanbaru. (2019). Rekapitulasi Data Jumlah Kasus dan Kematian Tifoid Kota Pekanbaru Tahun 2019. Pekanbaru.

Kementerian Kesehatan RI. (2006). Pedoman Pengendalian Demam Tifoid. Jakarta: Badan Penelitian dan Pengembangan Kementerian Kesehatan RI.

Maghafirah, M., Sukismanto, S., \& Rahmuniyati, M. E. (2018). Hubungan Pengetahuan dan Sikap Dengan Praktik Hygiene Sanitasi Penjamah Makanan Di Sepanjang Jalan Raya Tajem Maguwoharjo Yogyakarta Tahun 2017. JURNAL FORMIL (Forum Ilmiah) KesMas Respati, 3(1), 15-22. Retrieved from http://formilkesmas.respati.ac.id/index.php/formil/article/view/108/64

Mardhatillah, M. (2019). Hubungan Pengetahuan Dan Sikap Degan Hygiene Penjamah Makanan di Kantin SDN Se-Kecamatan Kampar. PREPOTIF Jurnal Kesehatan Masyarakat, 3(1), 68-79. https://doi.org/https://doi.org/10.31004/prepotif.v3i1.444

Received: November 2021, Accepted : November 2021 - Jurnal Photon Vol.12 No.1

DOI : https://doi.org/10.37859/jp.v12i1.3166

PHOTON is licensed under a Creative Commons Attribution-ShareAlike 4.0 International License 
Photon

Jurnal Sains dan Kesehatan

E-15SN : 2579-5953

P-155N : 2087-393X

http://ejurnal.umri.ac.id/index.php/photon

Miranti, E. A., \& Adi, D. C. (2016). Hubungan Pengetahuan dan Sikap Dengan Higiene Perorangan (Personal Hygiene) Penjamah Makanan Pada Penyelenggaraan Makanan Asrama Putri. Media Gizi Indonesia, 11(2), 120-126. https://doi.org/http://dx.doi.org/10.20473/mgi.v11i2.120-126

Notoatmodjo, S. (2010). Konsep Perilaku Kesehatan. Promosi Kesehatan : Teori dan Aplikasi Edisi Revisi. Jakarta: Rineka Cipta.

Notoatmodjo, S. (2014). Ilmu Perilaku Kesehatan. Jakarta: Rineka Cipta.

Nyamusore, J., Nahimana, M. R., Ngoc, C. T., Olu, O., Isiaka, A., Ndahindwa, V., ... Rusanganwa, A. (2018). Risk factors for transmission of Salmonella Typhi in Mahama refugee camp, Rwanda: A matched case-control study. Pan African Medical Journal, 29, 1-13. https://doi.org/10.11604/pamj.2018.29.148.12070

Oktafiani, I., \& Hendriyani, H. (2015). Hubungan Pengetahuan dan Sikap Higiene Sanitasi Dengan Praktik Higiene Sanitasi Pemasak Makanan Dan Mutu Biologi Pada Lauk Hewani di RSUD Kota Semarang. Jurnal Riset Gizi, 3(1), 19-25. Retrieved from https://ejournal.poltekkessmg.ac.id/ojs/index.php/jrg/article/view/4322/1174

Pasanda, A. (2016). Perbedaan Pengetahuan, Sikap, dan Perilaku Penjamah Makanan Sesudah Diberikan Penyuluhan Personal Higiene Di Hotel Patra Jasa Semarang. Universitas Muhammadiyah Semarang. Retrieved from http://repository.unimus.ac.id/93/1/SKRIPSI FULL TEXT.1.pdf

Ramaningrum, G., Anggraheny, H. D., \& Puteri, T. P. (2016). Faktor-faktor yang Mempengaruhi Kejadian Demam Tifoid pada Anak di RSUD Tugurejo Semarang. Jurnal Kedokteran Muhammadiyah, 5(2), 1-8. Retrieved from https://jurnal.unimus.ac.id/index.php/kedokteran/article/view/2596/2445

Setiati, S., \& Alwi, I. (2017). Buku Ajar Ilmu Penyakit Dalam. Jakarta: Interna Publishing.

Ulfa, F., \& Handayani, O. W. K. (2018). Kejadian Demam Tifoid di Wilayah Kerja Puskesmas Pagiyanten. HIGEIA (Journal of Public Health Research and Development), 2(2), 227-238. https://doi.org/https://doi.org/10.15294/higeia.v2i2.17900

Received: November 2021, Accepted : November 2021 - Jurnal Photon Vol.12 No.1

DOI : https://doi.org/10.37859/jp.v12i1.3166

PHOTON is licensed under a Creative Commons Attribution-ShareAlike 4.0 International License 